\title{
Impact of a Non-Saccharomyces Yeast Isolated in the Equatorial Region in the Acceptance of Wine Aroma
}

\author{
Mariana Oliveira Assis ${ }^{1}$, Adriana Pereira Coelho Santos ${ }^{1}$, Carlos Augusto Rosa ${ }^{2}$, \\ Maria Eugênia de Oliveira Mamede ${ }^{1}$ \\ ${ }^{1}$ Department of Food Science, Faculty of Pharmacy, Federal University of Bahia, Bahia, Brazil \\ ${ }^{2}$ Department of Microbiology, Institute of Biology, Federal University of Minas Gerais, Belo Horizonte, Brazil \\ Email: mmamede@ufba.br
}

Received 17 January 2014; revised 17 February 2014; accepted 24 February 2014

Copyright (C) 2014 by authors and Scientific Research Publishing Inc.

This work is licensed under the Creative Commons Attribution International License (CC BY). http://creativecommons.org/licenses/by/4.0/

(c) (i) Open Access

\section{Abstract}

The aim of this work was to isolate and identify the yeasts prevalent in fresh grapes cultivated in the "São Francisco Valley" region (Brazil), as well as evaluating the cell growth of these indigenous yeasts during the fermentation of grape musts and their contribution to the improvement of wine aroma. The Chenin Blanc grape must fermented by $H$. opuntiae presented higher acceptance means at the three points analyzed $(6.74,6.78$ and 7.30$)$ and in the fermentation carried out by the yeasts $H$. opuntiae and $S$. cerevisiae, the highest mean acceptance (7.22) was observed after 120 hours, with no statistical difference from the sample fermented by $H$. opuntiae alone. Since these samples that showed higher acceptance means also receiving higher scores for purchasing intention, corresponding to the concepts of "definitely would buy" and "probably would buy". The present study suggests that the fermentations of grape musts carried out by the yeast $H$. opuntiae and mixed cultures of $\mathrm{H}$. opuntiae and Saccharomyces cerevisiae, positively influenced the sensory qualities of the wines and showed greater potential to increase the aroma of the musts and to develop specific wine styles.

\section{Keywords}

Aroma; Fermentation; Non-Saccharomyces; Saccharomyces cerevisiae Variety Bayanus; Sensory Analysis; Vitis vinifera $\mathrm{L}$. 


\section{Introduction}

Wine consumption and production are increasing in Brazil and in 2012 wine production accounted for a planted area of 82.507 million hectares, producing about 260 million liters and a per capita annual consumption of 2 liters, 0.3 liters more as compared to the per capita consumption in 2009 [1]. Increasingly consumers search for differentiated wines with pleasant sensory aspects and sustainable production [2]-[4].

The importance of the whole wine fermentation process is currently acknowledged, and not merely as a simple process of using sugar to produce alcohol. The alcoholic fermentation of the wine is the key in the quest for innovation or the creation of biotechnology that will change the expanding market [5]. It has been well known for a long time that the grape contains a diversity of yeast species, including Hanseniaspora (anamorph of Kloeckera), Pichia, Candida, Kluyveromyces and Saccharomyces, and very occasionally the yeasts Zygosaccharomyces and Torulaspora, amongst others [6]. It is also known that these yeasts start the fermentation process, but are quickly suppressed by the rapid growth of the yeast Saccharomyces cerevisiae, which continues the fermentation process up to the point of obtaining the final product [7]. With special resourcefulness Saccharomyces cerevisiae var. bayanus was considered the species of greatest importance in these processes, and became the culture "starter" most frequently used in wine production [5]. For a long time it was believed that non-Saccharomyces yeasts could not contribute positively to wine quality, and could actually hinder the development of the Saccharomyces. However, some studies in different regions of the world have shown the importance of non-Saccharomyces in the growth kinetics during spontaneous fermentations or fermentations with an inoculum of commercial Saccharomyces [8]-[12], and others have shown the importance of non-Saccharomyces in impacting the sensory quality of wine aroma [13]-[15].

The "São Francisco Valley" region is located between the $9^{\circ}$ and $10^{\circ}$ south latitude, and is the wine-producing region closest to the equator in the world. Currently there is an area equivalent to 700 hectares of grapevines in this region, planted with cultivars that result in the production of approximately 7 million liters of wine per year, of which $80 \%$ is red and $20 \%$ white [16].

The spontaneous fermentation of wine deserves to be studied, since it presents the potential to create a differentiated product with innovative character. The possibility of selecting microorganisms to influence wine style and possibly consumer appreciation provides wine makers with a valuable additional tool to produce wines that meet consumer demand in a globally competitive market [17].

Given the above, the aim of the present study was to isolate and identify the yeasts prevalent in fresh grapes cultivated in the "São Francisco Valley" region (BA/PE, Brazil), as well as evaluating the cell growth of these indigenous yeasts during the fermentation of grape musts and their contribution to the improvement of wine aroma.

\section{Materials and Methods}

The present study was developed at the following laboratories: Laboratory for Research in Food Microbiology and Sensory Analysis Laboratory of the Department of Bromatological Analysis, Faculty of Pharmacy of the Federal University of Bahia/UFBA. The yeasts were identified at the Laboratory of Yeast Biotechnology and Ecology of the Institute of Biology of the Federal University of Minas Gerais/UFMG.

\subsection{Yeast Strain}

The yeasts Hanseniaspora opuntiae and Cryptococcus flavescens were obtained from grapes cultivated in the municipalities of Villa Nova (BA-Brazil) located at 380 meters of altitude, latitude South $09^{\circ} 05^{\prime} 00^{\prime \prime}$ and longitude 40 37'00"; Lagoa Grande (PE-Brazil) at 361 meters, 859'47" south latitude and longitude 40¹6'18" and Santa Maria da Boa Vista (PE-Brazil) located at 371 meters of altitude, latitude South $8^{\circ} 47^{\prime} 58^{\prime \prime}$ and longitude 39 49'39", and isolated following the method of Assis et al. [18]. After the biochemical study, the non-Saccharomyces yeasts were identified by sequencing of the D1/D2 region of the 26S subunit of the ribosomal RNA [19].

The pure colonies were maintained on Yeast Malt Agar (YMA) (1\% glucose, 2\% agar, 0.5\% peptone, 0.3\% malt extract and $0.3 \%$ yeast extract) slopes with the addition of sterile glycerol (Vetec) and kept under refrigeration $\left(4^{\circ} \mathrm{C}\right)$ for 30 days, and re-streaked every 15 days, for later use. 


\subsection{Must and Fermentation Conditions}

Chenin Blanc, Cabernet Sauvignon and Rosé grape musts, donated by Rio Sol, located in the state of Pernambuco (Brazil), were used for the investigation of aroma formation by the yeasts $H$. Opuntiae and C. Flavescens in the wine. The commercial yeast S. cerevisiae var. bayanus (Maurivin) was used as the control in the fermentation process. The fermentations were carried out in triplicate at temperatures of $15^{\circ} \mathrm{C}$ for Chenin Blanc grape must and $25^{\circ} \mathrm{C}$ for the Cabernet Sauvignon and Rosé grape musts for seven days.

The inoculums of S. cerevisiae var. bayanus, Hanseniaspora opuntiae and Cryptococcus flavescens were previously activated in YM medium and incubated in a BOD incubator (Alfakit) for 48 hours at $28^{\circ} \mathrm{C}$. The inoculums were then standardized at $1 \times 10^{6}$ yeast cells/ml according to the McFarland scale and reading in a spectrophotometer (Femto $800 \mathrm{XI}$ ) with an optical density range of 0.08 to 0.1 and wavelength of $625 \mathrm{~nm}$. An aliquot of $1 \mathrm{~mL}$ of the standardized suspension was removed and inoculated into $250 \mathrm{~mL}$ conical flasks containing $83.3 \mathrm{~mL}$ of filtered must. The samples were placed in a model TE-424 temperature controlled orbitalshaker, (Tecnal) at $100 \mathrm{rpm}$ for 168 hours (7 days) at temperatures of $15^{\circ} \mathrm{C}$ for the Chenin Blanc grape must and $25^{\circ} \mathrm{C}$ for the Cabernet Sauvignon and Rosé grape musts.

The kinetic parameters were evaluated every 24 hours of fermentation. Aliquots of $83.3 \mathrm{ml}$ of fermented must were filtered through a Millipore membrane $(0.22 \mu \mathrm{M}$ pore) to determine the cell concentration. The cell concentration, expressed as the Dry Matter (DM) in $\mathrm{mg} / \mathrm{L}$, was quantitatively determined by drying the membranes at $100^{\circ} \mathrm{C}$ for 24 hours and division the weight by the corresponding volume filtered. The DM values (mg/L) were the averages of the measurements taken every 24 hours. The filtrate was collected and its $\mathrm{pH}$ determined using a pH meter (Phtek/P100).

\subsection{Sensory Analyses}

The typical wine aroma of the grape musts, fermented by yeasts, was evaluated after different periods of fermentation (72 h, $96 \mathrm{~h}$ and $120 \mathrm{~h}$ ), using sensory affective tests of acceptability and purchasing intention. A total of 50 judges were recruited based on their wine consumption frequency.

A 9-cm non-structured hedonic scale was used in the acceptability test with extremes of "(1) disliked extremely" and "(9) liked extremely" [20]. The weighed and codified samples were presented to the judges in different sessions. The consumers also registered their purchasing intentions for each ample on the same score sheet, using a five-point attitude scale, with extremes of "(1) would definitely buy" and "(5) would definitely not buy".

The results obtained in the affective sensory tests were evaluated by the analysis of variance (ANOVA) and Tukey's test $(p<0.05)$ using the 6.11 SAS version. The results for purchasing intention were presented as a frequency histogram.

The study plan was evaluated by the Research Ethics Committee of the Federal University of Bahia-UFBA, resolution number 01 of 13/06/1988-CNS, who presenting a favorable opinion for the development of the study (number 094/2009 and CEP record 102/2009).

\subsection{Chemical Composition of the Musts}

The Chenin Blanc, Cabernet Sauvignon and Rosé grape musts were characterized according to the parameters $\mathrm{pH}$, total acidity and soluble solids. The $\mathrm{pH}$ was measured in a digital $\mathrm{pH}$ meter (Phtek/P100), the total acidity determined by titration according to Ough and Amerine [21], and the soluble solids, expressed as ${ }^{\circ}$ Brix, using a manual refractometer (Atago/2313).

The $\mathrm{SO}_{2}$ and nitrogen concentrations present in the grape musts were determined in the wineries and the information ceded to carry out this study.

\section{Results and Discussion}

The chemical compositions of the grape musts were determined to check if the musts were in the ideal conditions to start fermentation. According to Boulton et al. [22] and Heard and Fleet [23] the $\mathrm{pH}$ of the grape must should be between 2.8 and 4.4 to start fermentation. The $\mathrm{pH}$ values found in the must used in this study varied from 3.2 to 3.6 .

The highest total acidity value was found in the Rosé grape must $(128.1 \mathrm{mEq} / \mathrm{L})$, followed by the Chenin 
Blanc $(84.0 \mathrm{mEq} / \mathrm{L})$ and Cabernet Sauvignon $(82.1 \mathrm{mEq} / \mathrm{L})$. As for the $\mathrm{pH}$ values, the total acidity values were also within the ideal values for fermentation [22].

The soluble solids content (SS) is a fairly accurate indicator of the sugar content in the musts and represents the ability to sustain the production of alcohol by yeasts [24]. According to Mandelli and Zanus [25], the SS of the grapes for the production of red, white and sparkling wines should present values between $17-22^{\circ} \mathrm{Brix}$, and may vary depending on the type of wine. The values found in the musts were: Chenin Blanc ( $\left.19^{\circ} \mathrm{Brix}\right)$, Cabernet Sauvignon $\left(18^{\circ} \mathrm{Brix}\right)$ and Rosé $\left(15^{\circ} \mathrm{Brix}\right)$. In this study, only the Rosé grape must did not reach the ideal value for ${ }^{\circ}$ Brix to maintain fermentation for a long period. According to Bisson [26] fermentation for a long period of time (25 to 55 days) requires the presence of a large amount of sugar in the must, but this was not the case in the present study, because the research into the fermentative behavior and aroma production only took place for seven days. The efficient use of substrates present in the grape musts, such as glucose and fructose, leads to increased cell growth and consequently increase Dry Matter (DM) values or biomass [27]-[29].

The $\mathrm{SO}_{2}$ concentrations found in the grape musts were: Chenin Blanc ( $\left.50.0 \mathrm{mg} / \mathrm{L}\right)$, Cabernet Sauvignon (35.0 $\mathrm{mg} / \mathrm{L})$ and Rosé $(50.0 \mathrm{mg} / \mathrm{L})$. Under current Brazilian legislation, the maximum total concentration of $\mathrm{SO}_{2}$ allowed in wine is $350 \mathrm{mg} / \mathrm{L}$ [30] and hence the total $\mathrm{SO}_{2}$ concentrations found in the grape must samples were also within the ideal limits for fermentation.

The ammonium nitrogen concentration found in the Rosé grape must was $92.0 \mathrm{mg} / \mathrm{L}$, that in the Chenin Blanc $116.0 \mathrm{mg} / \mathrm{L}$ and that in the Cabernet Sauvignon $98.0 \mathrm{mg} / \mathrm{L}$. According to Bisson [26] the minimum ammonium nitrogen concentration in the must should be between 70.0 and $140.0 \mathrm{mg} / \mathrm{L}$.

The $\mathrm{pH}$ of the Chenin Blanc, Cabernet Sauvignon and Rosé grape musts did not suffer great variations, remaining between 3.3 and 3.1 during fermentation by the strains studied (data not shown). According to Serra et al. [28] and Ribéreau-Gayon et al. [29] the pH of the fermented must can range between 2.3 and 4.3, and this variation is not considered to be a factor that will increase or decrease the values of biomass.

Mamede and Pastore [31] evaluated the variation in cell growth of Pinot Noir and Chardonnay grape musts fermented by the yeasts Kloeckera apiculata and S. cerevisiae by determining the dry cell mass at a temperatures of $15^{\circ} \mathrm{C}$ and $20^{\circ} \mathrm{C}$, and concluded that cell growth was slow at a temperature of $15^{\circ} \mathrm{C}$ and that the exponential phase varied between 72 and 96 hours for the two yeasts studied. These authors carried out a similar study in 2007 using the yeast Pichia membranaefaciens at a temperature of $15^{\circ} \mathrm{C}$, and observed that cell growth was rapid and vigorous in the first 72 hours, with maximum dry cell mass values of $10.6 \mathrm{mg} / \mathrm{L}$ and $10.3 \mathrm{mg} / \mathrm{L}$ in the Chardonnay and Pinot noir grape musts respectively. Meantime, in the present study the exponential phase (log phase) of the strains occurred during the first 24 hours of fermentation, as evidenced by the increase in dry cell mass expressed as dry matter (DM) (Figures 1-3).

Cortés et al. [32] concluded that high temperature fermentations led to sweeter wines with higher volumetric productivities, although low temperature fermentations produced better wines in terms of higher glycerol and lower acid levels.

For the Chenin Blanc grape must fermented by $H$. opuntiae at $15^{\circ} \mathrm{C}$ (Figure 1), the maximum value for DM was obtained after 120 hours $(3.8 \mathrm{mg} / \mathrm{L})$, after which there was a decrease in the production of DM $(2.1 \mathrm{mg} / \mathrm{L})$. However there was a new evolution after 168 hours fermentation, giving a DM value of $2.8 \mathrm{mg} / \mathrm{L}$. The same must fermented by $C$. flavescens reached a maximum value of DM after 144 hours $(5.0 \mathrm{mg} / \mathrm{L})$, and the fermentation carried out by $S$. Cerevisiae produced the highest DM value (6.1 mg/l) after 120 hours.

The Rosé grape must fermented by $\mathrm{H}$. opuntiae at $25^{\circ} \mathrm{C}$ (Figure 2) reached a maximum DM value of 6.9 $\mathrm{mg} / \mathrm{L}$ after 120 hours of fermentation, and then showed a slight decline. The fermentation carried out by C. flavescens reached its highest DM value $(5.4 \mathrm{mg} / \mathrm{l})$ after 120 hours of fermentation, and then showed a marked decline. As for fermentation by $S$. cerevisiae, the maximum DM value of $9.7 \mathrm{mg} / \mathrm{L}$ was reached after 72 hours, then entering a stationary phase after 96 hours, with an unobtrusive decline in DM.

The fermentations carried out by the yeasts $H$. opuntiae and C. Flavescens in the Cabernet Sauvignon grape must (Figure 3) at $25^{\circ} \mathrm{C}$, reached their highest DM values at $\mathrm{pH} 3.1$ after 120 hours, the values being $5.4 \mathrm{mg} / \mathrm{L}$ and $5.2 \mathrm{mg} / \mathrm{L}$, respectively. The fermentation carried out by S. cerevisiae reached a maximum DM value (10.6 $\mathrm{mg} / \mathrm{L}$ ) after 48 hours at $\mathrm{pH} 3.2$, remaining at this value up to 120 hours of fermentation, after which a slight decline to $10.1 \mathrm{mg} / \mathrm{L}$ was observed. The production of DM in the fermentation carried by the yeast $C$. flavescens declined after 120 hours, with no stationary phase being observed.

The evaluation of the fermentative behavior in the Chenin Blanc, Cabernet Sauvignon and Rosé grape musts showed that all yeast cell growth continued for 5 - 6 days (120 and 144 hours), with the exception of S. cerevisiae 


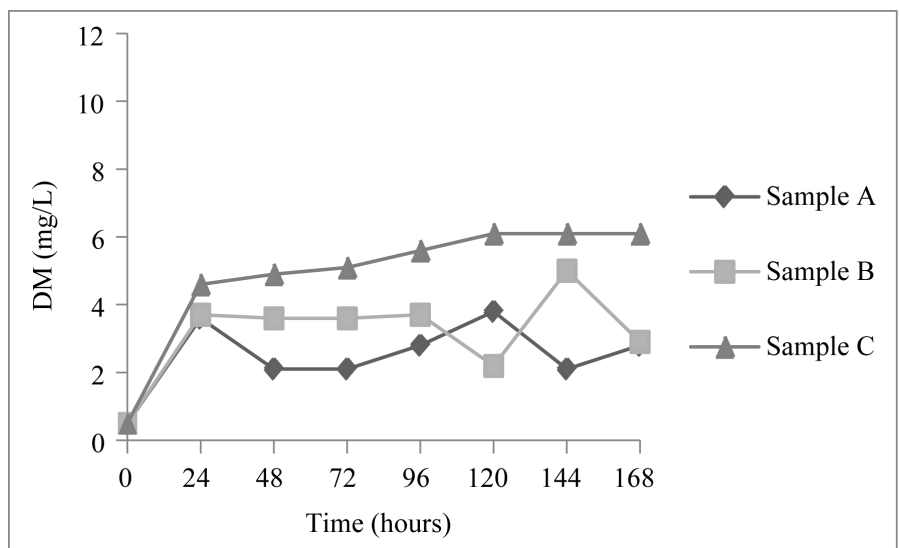

Figure 1. Cell concentration expressed as dry matter (DM) (mg/L), in the fermentation by Hanseniaspora opuntiae (Sample A), Cryptococcus flavescens (Sample B) and Saccharomyces cerevisiae (Sample C) in Chenin blanc grape must at $15^{\circ} \mathrm{C}$.

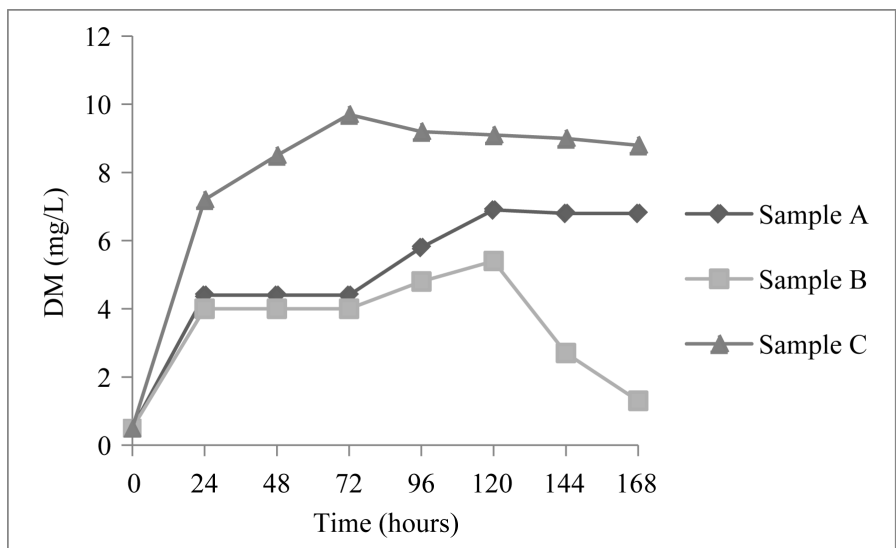

Figure 2. Cell concentration expressed as dry matter (DM) (mg/L), in the fermentation by Hanseniaspora opuntiae (Sample A), Cryptococcus flavescens (Sample B) and Saccharomyces cerevisiae (Sample C) in Rosé grape must at $25^{\circ} \mathrm{C}$.

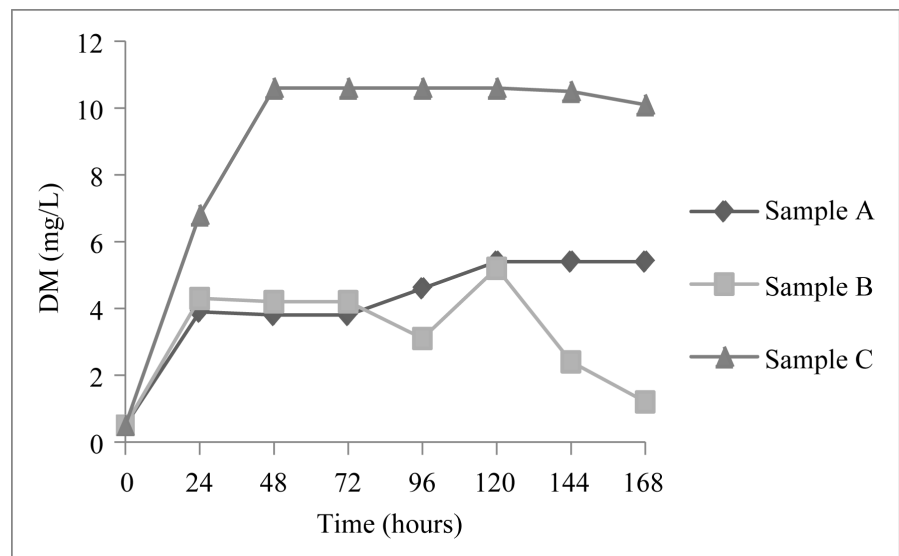

Figure 3. Cell concentration expressed as dry matter (DM) (mg/L), in the fermentation by Hanseniaspora opuntiae (Sample A), Cryptococcus flavescens (Sample B) and Saccharomyces cerevisiae (Sample C) in Cabernet sauvignon grape must at $25^{\circ} \mathrm{C}$. 
in the Cabernet Sauvignon grape must (Figure 3), in which significant cell growth (the log phase) only lasted for 2 days.

According to Zamora [33], the log phase for the yeast S. cerevisiae typically lasts for 3 to 6 days (72 to $144 \mathrm{~h}$ ). Similar data were found by Sener et al. [34] when studying the fermentation kinetics of S. cerevisiae in wine produced on a laboratory scale. In the adaptation phase, aeration of the grape must is recommended to favor exponential growth of the yeast, mainly by promoting the synthesis of the cytoplasm membrane constituents (sterols, fatty acids and phospholipids) and avoiding stuck and slugging-type fermentations [29].

According to Berovic et al. [27] the temperature is one of the most significant parameters affecting the fermentation process and the production of various metabolic products that directly reflect on the quality of the wine. Heard and Fleet [23] reported that low temperatures (between $10^{\circ} \mathrm{C}$ and $20^{\circ} \mathrm{C}$ ) favor the growth and persistence of Kloeckera spp. (telemorfa Hanseniaspora spp.) and Candida spp. during the fermentation process.

In the present study, the greatest cell concentrations were observed in the fermentations submitted to a temperature of $25^{\circ} \mathrm{C}$ as compared to those at $15^{\circ} \mathrm{C}$. A similar result was observed by Mamede and Pastore [31] who obtained a dry cell mass of $12.4 \mathrm{mg} / \mathrm{l}$ (expressed as dry mass) during the fermentation of Chardonnay and Pinot Noir grape musts by $S$. cerevisiae at $20^{\circ} \mathrm{C}$, whereas at $15^{\circ} \mathrm{C}$ it was only $10.4 \mathrm{mg} / \mathrm{L}$.

During the fermentation process, the sugars and amino acids are metabolized to produce ethanol and other compounds that reflect on the acceptability of the aroma. These volatile compounds vary significantly between different yeast species, so it is necessary to select for those yeasts that contribute positive attributes to the aroma [3] [7].

The typical wine aroma in the fermented musts was evaluated using a sensory acceptability test, applied at three distinct points during the fermentation ( $72 \mathrm{~h}, 96 \mathrm{~h}$ and $120 \mathrm{~h}$ ). The Chenin Blanc grape must fermented by H. opuntiae presented higher acceptance means at the three points analyzed (6.74, 6.78 and 7.30) (Table 1).

In the fermentation carried out by the yeasts $H$. opuntiae and $S$. cerevisiae, the highest mean acceptance (7.22) was observed after 120 hours, with no statistical difference from the sample fermented by $H$. opuntiae alone. The fermentations carried out by the commercial yeast $S$. cerevisiae var. bayanus alone showed the lowest mean acceptances of 4:18, 3.78 and 4.30 at the time points of $72 \mathrm{~h}, 96 \mathrm{~h}$ and 120 hours, respectively, and were statistically different $(p>0.05)$ from the other samples tested. This shows that $H$. opuntiae contributed to enhancing the aroma of the wine. King et al. [35] observed that the wine made from the Sauvignon blanc grape must using two different yeast strains of $S$. cerevisiae showed a higher mean acceptance for flavor as attributed by 120 judges, when compared to the wine produced with only one strain of $S$. cerevisiae.

The Rosé grape must fermented by the yeasts $H$. opuntiae and $S$. cerevisiae presented higher mean acceptances (7.16 and 7.12) for aroma at the time points of 72 and 96 hours of fermentation, with no statistical difference $(p<0.05)$ from samples 1 and 9 (Table 2). The lowest mean acceptance $(2.78)$ was for the must fermented

\begin{tabular}{|c|c|c|}
\hline Time of sensory analysis & Samples & Mean acceptances \\
\hline \multirow{4}{*}{72 hours of fermentation } & 1 (H. opuntiae) & $6.74^{\text {ba }}$ \\
\hline & 2 (C. flavescens) & $5.90^{\mathrm{bc}}$ \\
\hline & 3 (S. cerevisiae) & $4.18^{\mathrm{d}}$ \\
\hline & 4 (S. cerevisiae \& H. opuntiae) & $5.96^{\mathrm{bc}}$ \\
\hline \multirow{4}{*}{96 hours of fermentation } & 5 (H. opuntiae) & $6.78^{\text {ba }}$ \\
\hline & 6 (C. flavescens) & $5.80^{\mathrm{bc}}$ \\
\hline & 7 (S. cerevisiae $)$ & $3.78^{\mathrm{d}}$ \\
\hline & 8 (S. cerevisiae \& H. opuntiae) & $5.52^{\mathrm{c}}$ \\
\hline \multirow{4}{*}{120 hours of fermentation } & 9 (H. opuntiae) & $7.30^{\mathrm{a}}$ \\
\hline & 10 (C. flavescens) & $2.74^{\mathrm{e}}$ \\
\hline & $11($ S. cerevisiae $)$ & $4.30^{\mathrm{d}}$ \\
\hline & 12 (S. cerevisiae \& H. opuntiae) & $7.22^{\mathrm{a}}$ \\
\hline
\end{tabular}

Means with the different letter differ significantly according to Tukey's test $(p<0.05)$. 
by C. flavescens after 96 hours, with a statistical difference $(p>0.05)$ from the other samples tested.

The acceptability of the aroma of the Cabernet Sauvignon grape must was low in relation to the acceptability of the aromas of the Chenin Blanc and Rosé grape musts, and the combination of S. cerevisiae and H. opuntiae presented higher mean acceptances (5.26 and 5.66) after 72 and 96 hours, respectively (Table 3). The lowest mean acceptances of 4.22, 4.04 and 3.40 were obtained for the fermentations carried out by the commercial yeast $S$. cerevisiae var. bayanus after 72, 96 and 120 hours, respectively, with a statistical difference $(p>0.05)$ from the sample with the highest mean acceptance (sample 8).

The Chenin Blanc grape must fermented by $H$. Opuntiae and the combination of $H$. opuntiae and S. cerevisiae presented the highest scores for purchasing intention, corresponding to the concepts of "definitely would buy" and "probably would buy", with scores of $76 \%$ and $70 \%$ respectively after 120 hours of fermentation (Figure 4). Since these samples showed the highest mean acceptances, they also obtained the highest scores for purchasing intention.

For the Rosé grape must, the sample fermented by the yeasts $H$. opuntiae and S. cerevisiae showed the highest

Table 2. Acceptability tests for the aroma of Rosé must fermented at $25^{\circ} \mathrm{C}$.

\begin{tabular}{ccc}
\hline Time of sensory analysis & Samples & Mean acceptances \\
\hline \multirow{3}{*}{72 hours of fermentation } & 1 (H. opuntiae) & $6.20^{\mathrm{bac}}$ \\
& 2 (C. flavescens) & $6.96^{\mathrm{ba}}$ \\
3 (S. cerevisiae) & $5.70^{\mathrm{dc}}$ \\
& 4 (S. cerevisiae \& H. opuntiae) & $7.16^{\mathrm{a}}$ \\
96 hours of fermentation & 5 (H. opuntiae) & $4.76^{\mathrm{d}}$ \\
& 6 (C. flavescens) & $2.78^{\mathrm{e}}$ \\
7 (S. cerevisiae) & $6.04^{\mathrm{bac}}$ \\
120 hours of fermentation & 8 (S. cerevisiae \& H. opuntiae) & $7.12^{\mathrm{a}}$ \\
& 9 (H. opuntiae) & $6.14^{\mathrm{bac}}$ \\
& 10 (C. flavescens) & $5.84^{\mathrm{bdc}}$ \\
& 11 (S. cerevisiae) & $5.32^{\mathrm{dc}}$ \\
\hline
\end{tabular}

Means with the different letter differ significantly according to Tukey's test $(p<0.05)$.

Table 3. Acceptability tests for the aroma of Cabernet Sauvignon must fermented at $25^{\circ} \mathrm{C}$.

\begin{tabular}{ccc}
\hline Time of sensory analysis & Samples & Mean acceptances \\
\hline \multirow{2}{*}{72 hours of fermentation } & 1 (H. opuntiae) & $4.26^{\mathrm{bc}}$ \\
& 2 (C. flavescens) & $4.60^{\mathrm{bac}}$ \\
3 (S. cerevisiae) & $4.22^{\mathrm{bc}}$ \\
& 4 (S. cerevisiae \& H. opuntiae) & $5.26^{\mathrm{ba}}$ \\
96 hours of fermentation & 5 (H. opuntiae) & $4.54^{\mathrm{bac}}$ \\
& 6 (C. flavescens) & $4.54^{\mathrm{bac}}$ \\
7 (S. cerevisiae) & $4.04^{\mathrm{bc}}$ \\
120 hours of fermentation & 8 (S. cerevisiae \& H. opuntiae) & $5.66^{\mathrm{a}}$ \\
& 9 (H. opuntiae) & $5.02^{\mathrm{ba}}$ \\
& 10 (C. flavescens) & $5.24^{\mathrm{ba}}$ \\
& 11 (S. cerevisiae) & $3.40^{\mathrm{c}}$ \\
\hline
\end{tabular}

Means with the different letter differ significantly according to Tukey's test $(p<0.05)$. 
scores for purchasing intention corresponding to the concepts of "definitely would buy" and "probably would buy" after 72 hours (Figure 5) and 96 hours (Figure 6), with values of $72 \%$ and 74\%, respectively.

The Cabernet Sauvignon grape must fermented by the yeasts $H$. opuntiae and S. cerevisiae for 96 hours showed $32 \%$ of purchasing intention, corresponding to the concepts of "definitely would buy" and "probably would buy" (Figure 7).

Mamede et al. [15] evaluated the acceptability and purchasing intention of the aroma of Chardonnay and Pinot noir musts fermented at $15^{\circ} \mathrm{C}$ by the yeasts Pichia membranefaciens, Kloeckera apiculata, Candida valida and $S$. cerevisiae. The highest mean acceptances and purchasing intentions were obtained for the aroma of Pinot noir and Chardonnay musts fermented by P. membranefaciens and K. apiculata (5.50 and 5.43), respectively. The highest purchasing intention was for the Pinot noir grape must fermented by P. membranefaciens (35.5\%) and the Chardonnay grape must fermented only by S. cerevisiae showed lower acceptability (4.00) and purchasing intention (20\%). In the present study, the fermentations carried out only by $S$. cerevisiae also showed lower purchasing intention, corresponding to the concepts of "definitely would buy" and "probably would buy".

In the present study, it was observed that the results for purchasing intention were in accordance with the means for acceptance, with samples that showed higher acceptance means also receiving higher scores for purchasing intention, corresponding to the concepts of "definitely would buy" and "probably would buy". In addition the results showed that the higher mean acceptances of the aromas for the fermented Chenin Blanc, Cabernet

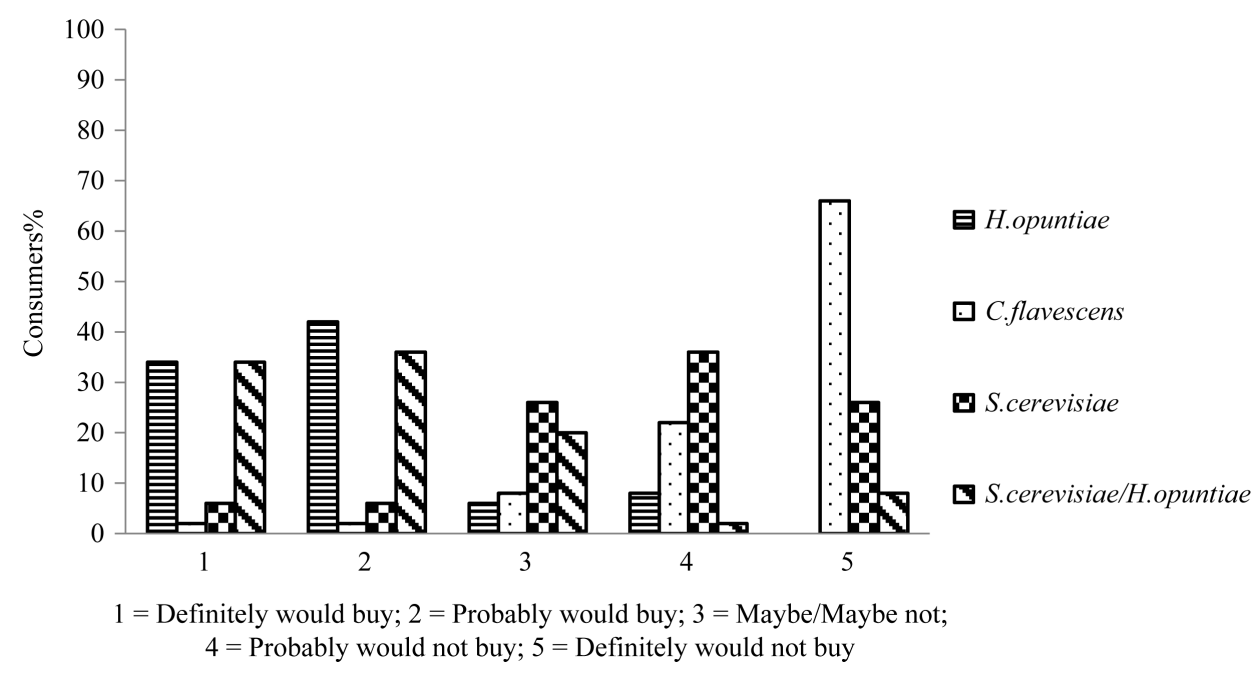

Figure 4. Consumer purchasing intention for Chenin blanc must fermented during 120 hours.

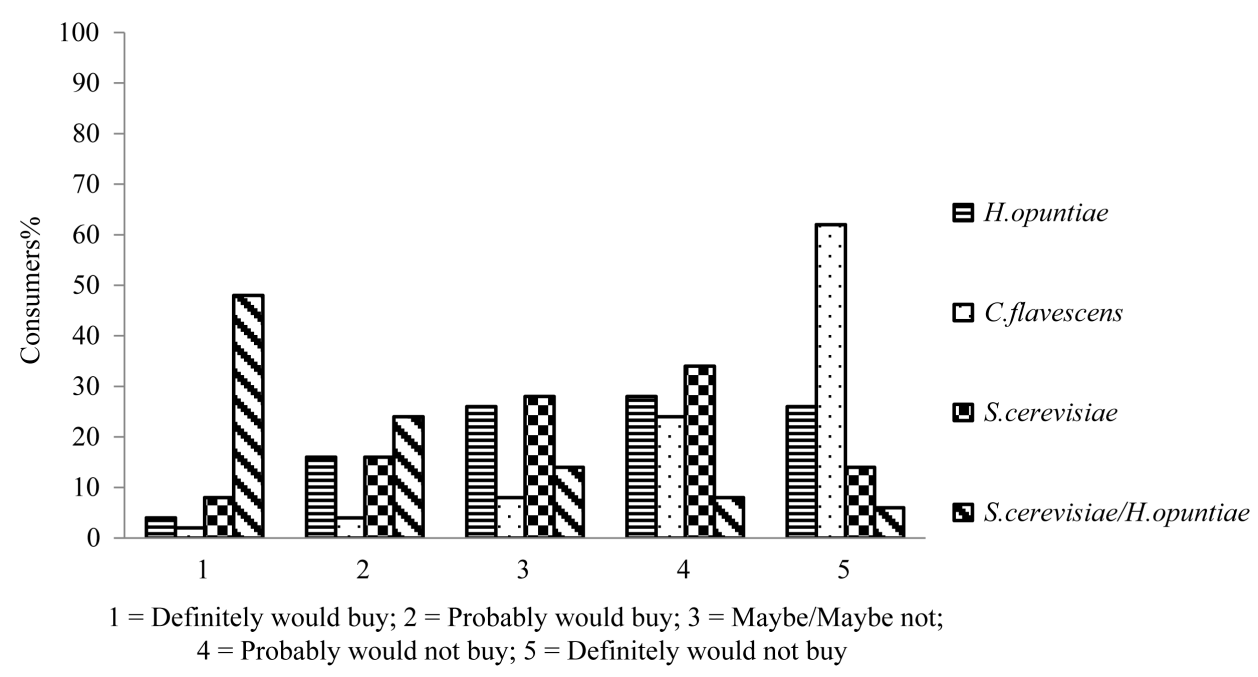

Figure 5. Consumer purchasing intention for Rosé must fermented during 72 hours. 


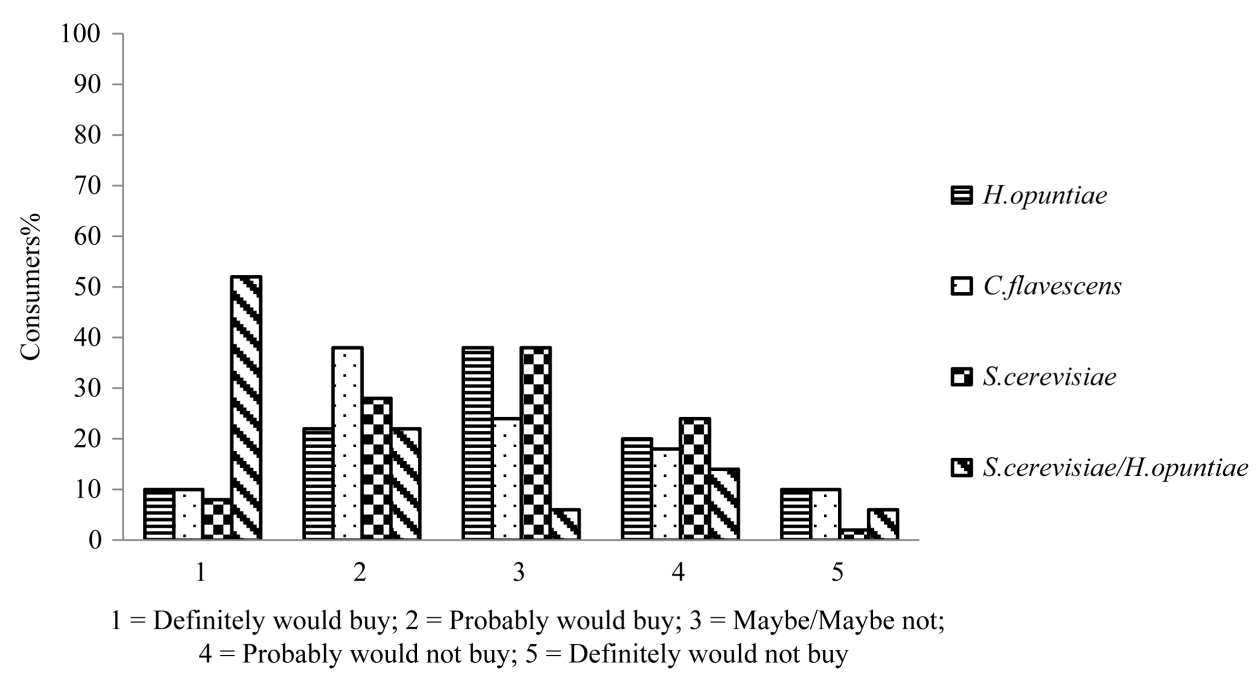

Figure 6. Consumer purchasing intention for Rosé must fermented during 96 hours.

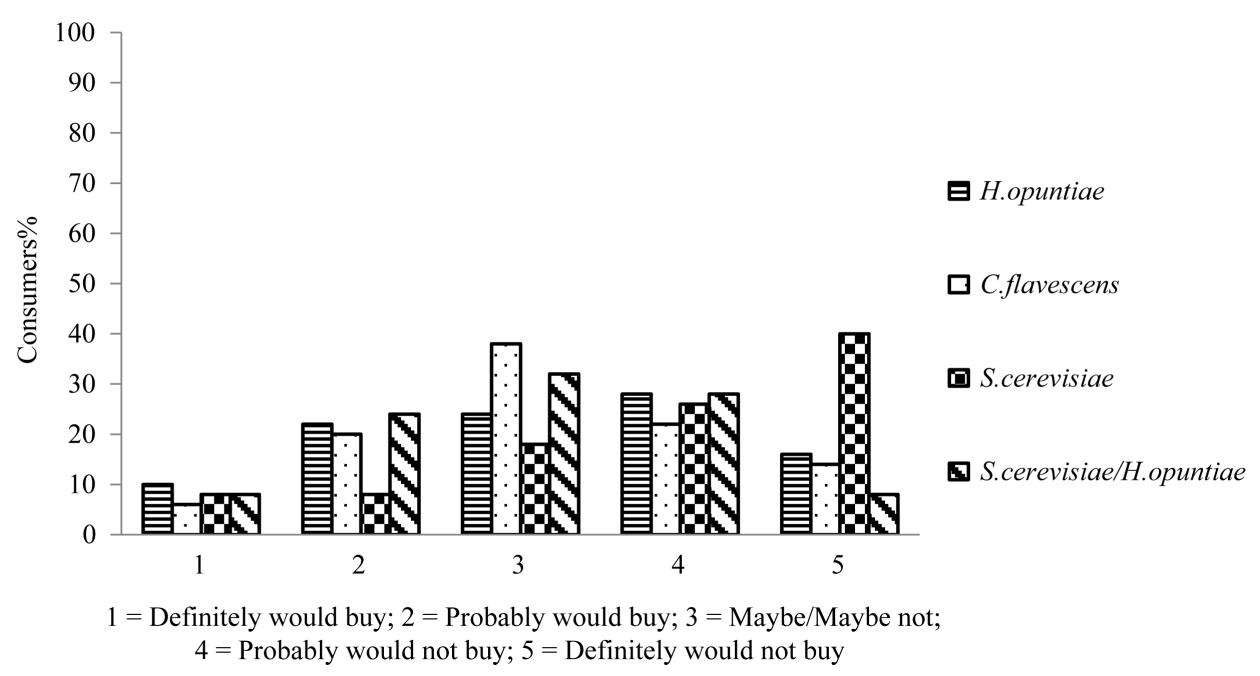

Figure 7. Consumer purchasing intention for Cabernet sauvignon must fermented during 96 hours.

Sauvignon and Rosé musts coincided with periods of increased cell growth of the yeasts. Molina et al. [36] found that most of the volatile aroma compounds (organic acids, ethyl esters and total alcohols) were synthesized during the exponential growth phase of the inoculated yeast in fermentations carried out at $15^{\circ} \mathrm{C}$ and $28^{\circ} \mathrm{C}$.

Many studies have been carried out using mixed cultures of non-Saccharomyces and Saccharomyces cerevisiae yeasts in wine fermentations, revealing a possible increase in the concentrations of volatile compounds that could contribute to the sensory quality of the product [37]-[40].

\section{Conclusions}

The fermentations of grape musts carried out by the yeast $H$. opuntiae, isolated in the São Francisco Valley region, showed greater potential to increase the aroma of the musts as compared to the other species studied. The use of $H$. opuntiae with S. cerevisiae var. bayanus in Chenin Blanc, Cabernet sauvignon and Rosé grape musts resulted in fermented musts with a typical wine aroma.

These characteristics positively influenced the sensory qualities of the wines produced with mixed cultures, which was reflected in the preference for these wines.

This study shows that the use of mixed cultures of non-Saccharomyces and Saccharomyces cerevisiae yeasts in fermentation processes could be a strategy to obtain distinctive wines using the native microorganisms from 
each winemaking area.

\section{Acknowledgements}

The authors would like to thank the Santa Maria winemaking (PE-Brazil). And the Fundação de Amparo a Pesquisa do Estado da Bahia (FAPESB) for the financial support.

\section{References}

[1] Mello, L.M.R. (2013) Brazilian Viticulture: Panorama 2012. Comunicado Técnico, 137. Embrapa Uva e Vinho, Bento Gonçalves. http://www.cnpuv.embrapa.br/publica/comunicado/cot137.pdf

[2] Bisson, L.F., Waterhouse, A.L., Ebeler, S.E.M., Walker, A. and Lapsley, J.T. (2002) The Present and Future of the International Wine Industry. Nature-International Weekly Journal of Science, 418, 696-699.

[3] Pretorius, I.S. and Hoj, P.B. (2005) Grape and Wine Biotechnology: Challenges, Opportunities and Potential Benefits. Australian Journal Grape Wine Research, 11, 83-108. http://dx.doi.org/10.1111/j.1755-0238.2005.tb00281.x

[4] Bernabéu, R., Brugarolas, M., Martínez-Carrasco, L. and Díaz, M. (2008) Wine Origin and Organic Elaboration, Differentiating Strategies in Traditional Producing Countries. British Food Journal, 110, 174-188.

http://dx.doi.org/10.1108/00070700810849899

[5] Fleet, G.H. (2008) Wine Yeasts for the Future. FEMS Yeast Research, 8, 979-995. http://dx.doi.org/10.1111/j.1567-1364.2008.00427.x

[6] Fleet, G.H. (2003) Yeast Interactions and Wine Flavor. International Journal of Food Microbiology, 86, 11-22. http://dx.doi.org/10.1016/S0168-1605(03)00245-9

[7] Fleet, G.H. and Heard, G.M. (1993) Yeast-Growth during Fermentation. In: Fleet, G.H., Ed., Harwood Academic, Wine, Microbiology and Biotechnology, Lausanne, 27-54.

[8] Rementeria, A., Rodriguez, J.A., Cadaval, A., Amenabar, R., Muguruza, J.R., Hernando, F.L. and Sevilla, M.J. (2003) Yeast Associated with Spontaneous Fermentations of White Wines from the "Txakoli de Bizkaia” Region (Basque Country, North Spain). International Journal of Food Microbiology, 86, 201-207. http://dx.doi.org/10.1016/S0168-1605(03)00289-7

[9] Combina, M., Mercado, P., Borgo, A.E., Jofré, V., Ganga, A., Martinez, C. and Catarina, C. (2005) Yeasts Associated to Malbec Grape Berries from Mendoza, Argentina. Journal of Applied Microbiology, 98, 1055-1061. http://dx.doi.org/10.1111/j.1365-2672.2005.02540.x

[10] Maro, E.D., Ercolini, D. and Coppola, S. (2007) Yeast Dynamics during Spontaneous Wine Fermentation of the Catalenesca Grape. International Journal of Food Microbiology, 117, 201-210. http://dx.doi.org/10.1016/j.ijfoodmicro.2007.04.007

[11] Sun, H., Ma, H., Hao, M., Pretorius, I.S. and Chen, S. (2009) Identification of Yeast Population Dynamics of Spontaneous Fermentation in Beijing Wine Region, China. Annals of Microbiology, 59, 69-76. http://dx.doi.org/10.1007/BF03175601

[12] Li, S.S., Cheng, C., Li, Z., Chen, J.Y., Yan, B., Han, B.Z. and Reeves, M. (2010) Yeast Species Associated with Wine Grapes in China. International Journal of Food Microbiology, 138, 85-90. http://dx.doi.org/10.1016/j.ijfoodmicro.2010.01.009

[13] Egli, C.M., Edinger, W.D., Mitrakul, C.M. and Henick-Kling, T. (1998) Dynamics of Indigenous and Inoculated Yeast Populations and Their Effect on the Sensory Character of Riesling and Chardonnay Wines. Journal of Applied Microbiology, 85, 779-789. http://dx.doi.org/10.1046/j.1365-2672.1998.00521.X

[14] Romano, P., Fiore, C., Paraggio, M., Caruso, M. and Capece, A. (2003) Function of Yeast Species and Strains in Wine Flavor. International Journal of Food Microbiology, 86, 169-180. http://dx.doi.org/10.1016/S0168-1605(03)00290-3

[15] Mamede, M.E.O., Cardello, H.M.A.B. and Pastore, G.M. (2005) Evaluation of an Aroma Similar to That of Sparkling Wine: Sensory and Gas Chromatography Analyses of Fermented Grape Musts. Food Chemistry, 89, 63-68. http://dx.doi.org/10.1016/j.foodchem.2004.02.012

[16] Silva, P.C., Correia, R.C. and Soares, J.M. (2009) Historical and Socio Economic Importance. In: Soares, J.M. and Souza, P.C., Eds., Embrapa Semi-Árido, A Vitivinicultura No Semiárido Brasileiro, Petrolina, 19-34.

[17] Malherbe, S., Menichelli, E., Du Toit, M., Tredoux, A., Muller, N., Naes, T. and Nieuwoudt, H. (2013) The Relationships between Consumer Liking, Sensory and Chemical Attributes of Vitis vinifera L. cv. Pinotage Wines Elaborated with Different Oenococcus oeni Starter Cultures. Journal of the Science of Food Agriculture, 93, 2829-2840. http://dx.doi.org/10.1002/jsfa.6115

[18] Assis, M.O., Mamede, M.E.O., Guimarães, A.G., Santos, L.S. and Rosa, C.A. (2012) Yeasts Isolated from Vitis vinífe- 
ra L. Grapes Yeasts of Equatorial Region. Instituto Adolfo Lutz, 71, 718-722.

[19] kurtzman, C.P., Fell, J.W. and Boekhout, J. (2011) The Yeasts, a Taxonomic Study. Elsevier, San Diego.

[20] Stone, H. andSidel, J.L. (2004) Descriptive Analysis. In: Stone, H. and Sidel, J.L., Eds., Academic Press, Sensory Evaluation Practices, Waltham, 215-235. http://dx.doi.org/10.1016/B978-012672690-9/50010-X

[21] Ough, C.S. and Amerine, M.A. (1988) Methods Analysis of Musts and Wines. John Wiley and Sons, New York.

[22] Boulton, R.B., Singleton, V.L., Bisson, L.F. and Kunkee, R.E. (1996) Yeast and Biochemistry of Ethanol Fermentation. In: Boulton, R.B., Ed., Principles and Practices of Winemaking, Aspen Publishers, Inc., Gaithersburg, 139-172.

[23] Heard, G.M. and Fleet, G.H. (1988) The Effects of Temperature and pH on the Growth of Yeast Species during the Fermentation of Grape Juice. Journal of Applied Microbiology, 65, 23-28.

[24] Jackson, R.S. (2008) Wine Science: Principles, Practice, Perception. Academic Press, San Diego.

[25] Mandelli, F. and Zanus, M.C. (2009) O clima e a safra vinícola. In: Guerra, C.C., Mandelli, F., Tornietto, J.M., Zanus, C. and Camargo, U.A., Eds., Embrapa, Conhecendo o essencial sobre uvas e vinhos, Bento Gonçalves, 31-34.

[26] Bisson, L.F. (1999) Stuck and Sluggish Fermentations. American Journal of Enology and Viticulture, 50, 107-119.

[27] Berovic, M., Mavrin, J., Wondra, M., Kosmerl, T. and Bavcar, D. (2003) Influence of Temperature and Carbon Dioxide on Fermentation of Cabernet Sauvignon Must. Food Technology and Biotechnology, 41, 353-359.

[28] Serra, A., Strehaiano, P. and Taillandier, P. (2005) Influence of Temperature and pH on Saccharomyces bayanus var. uvarum Growth; Impact of a Wine Yeast Interspecific Hybridization on These Parameters. International Journal of Food Microbiology, 104, 257-265. http://dx.doi.org/10.1016/j.ijfoodmicro.2005.03.006

[29] Ribérerau-Gayon, P., Dubourdieu, D., Doneché, B. and Lonvaund, A. (2006) Handbook of Enology-The Microbiology of Wine and Vinifications. Wiley, Chichester.

[30] Accessed on March 17, 2014. http://www.cnpuv.embrapa.br/publica/sprod/VinhoMoscatelEspumante/legislacao.htm

[31] Mamede, M.E.O. and Pastore, G.M. (2004) Evaluation of the Major Compounds Formed during Grape Must Fermentation by Yeast Isolated From "Serra Gaúcha” (RS) Region. Ciência e Tecnologia de Alimentos, 24, 453-458. http://dx.doi.org/10.1590/S0101-20612004000300026

[32] Cortés, S., Salgado, J.M., Rivas, B., Torrado, A.M. and Domínguez, J.M. (2010) Fermentation Kinetics and Chemical Characterisation of vino tostado, a Traditional Sweet Wine from Galicia (NW Spain). Journal of the Science of Food and Agriculture, 90, 121-131. http://dx.doi.org/10.1002/jsfa.3794

[33] Zamora, F. (2009) Biochemistry of Alcoholic Fermentation. In: Moreno, M.V.A. and Polo, M.C., Eds., Wine Chemistry and Biochemistry, Springer Science, New York, 3-26.

[34] Sener, F., Cambas, A. and Unal, M.U. (2007) The Effect of Fermentation Temperature on the Growth Kinetics of Wine Yeast Species. Turkish Journal of Agriculture and Forestry, 31, 349-354.

[35] King, E.S., Kievt, R.L., Curtin, C., Swiegers, J.H., Pretorius, I.S., Bastian, S.E.P. and Francis, I.L. (2010) The Effect of Multiple Yeasts Co-Inoculation on Sauvignon Blanc Wine Aroma Composition, Sensory Properties and Consumer Preference. Food chemistry, 122, 618-626. http://dx.doi.org/10.1016/j.foodchem.2010.03.021

[36] Molina, A.M., Swiegeres, J.H., Varela, C., Pretorius, I.S. and Agosin, E. (2007) Influence of Wine Fermentation Temperature on the Synthesis of Yeast-Derived Volatile Aroma Compounds. Applied Microbiology and Biotechnology, 77, 675-687. http://dx.doi.org/10.1007/s00253-007-1194-3

[37] Jemec, K.P., Cadez, N., Zagorc, T., Bubic, V., Zupec, A. and Raspor, P. (2001) Yeast Population Dynamics in Five Spontaneous Fermentations of Malvasia Must. Food Microbiology, 18, 247-259. http://dx.doi.org/10.1006/fmic.2001.0396

[38] Jolly, N.P., Augustyn, O.P.H. and Pretorius, I.S. (2006) The Role and Use of Non-Saccharomyces Yeasts in Wine Production. South African Journal for Enology and Viticulture, 27, 15-39.

[39] Ciani, M., Comitini, F., Mannazzu, I. and Domizio, P. (2010) Controlled Mixed Culture Fermentation: A New Perspective on the Use of Non-Saccharomyces Yeasts in Winemaking. FEMS Yeast Research, 10, 123-133. http://dx.doi.org/10.1111/j.1567-1364.2009.00579.x

[40] García, V., Vásquez, H., Fonseca, F., Manzanares, P., Viana, F., Martínez, C. and Ganga, M.A. (2010) Effects of Using Mixed Wine Yeast Cultures in the Production of Chardonnay Wines. Revista Argentina de Microbiologia, 42, 226-229. 